\title{
Immunomodulation Effects of Schizonepeta tenuifolia Briq. on the IgE-Induced Allergic Model of RBL-2H3 Cells
}

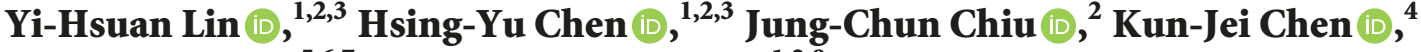 \\ Hung-Yao Ho $\mathbb{D}^{5,6,7}$ and Sien-Hung Yang ${ }^{1,2,8}$ \\ ${ }^{1}$ Division of Chinese Internal Medicine, Center for Traditional Chinese Medicine, Chang Gung Memorial Hospital, \\ Taoyuan 33378, Taiwan \\ ${ }^{2}$ School of Traditional Chinese Medicine, College of Medicine, Chang Gung University, Taoyuan 33302, Taiwan \\ ${ }^{3}$ Graduate Institute of Clinical Medical Sciences, College of Medicine, Chang Gung University, Taoyuan 33302, Taiwan \\ ${ }^{4}$ Division of Gastroenterology, Department of Pediatrics, Chang Gung Memorial Hospital, Linkou, Taoyuan 33305, Taiwan \\ ${ }^{5}$ Healthy Aging Research Center, Chang Gung University, Guishan, Taoyuan 33302, Taiwan \\ ${ }^{6}$ Clinical Phenome Center, Chang Gung Memorial Hospital, Linkou, Guishan, Taoyuan 33305, Taiwan \\ ${ }^{7}$ Department of Medical Biotechnology and Laboratory Science, College of Medicine, Chang Gung University, Taoyuan 33302, Taiwan \\ ${ }^{8}$ Chang Gung Immunology Consortium, Chang Gung Memorial Hospital and Chang Gung University, Guishan, \\ Taoyuan 33302, Taiwan
}

Correspondence should be addressed to Sien-Hung Yang; dryang@ms1.hinet.net

Received 14 November 2017; Revised 20 February 2018; Accepted 28 February 2018; Published 22 April 2018

Academic Editor: Yuan Xu

Copyright (C) 2018 Yi-Hsuan Lin et al. This is an open access article distributed under the Creative Commons Attribution License, which permits unrestricted use, distribution, and reproduction in any medium, provided the original work is properly cited.

Schizonepeta tenuifolia (ST) Briq. is a traditional herbal medicine commonly used to treat allergic skin diseases, where the inflammation process is closely related to symptom severity. This study aimed to explore the immunomodulatory effect of ST by using immunoglobulin E- (IgE-) stimulated RBL-2H3 cell cultures, a common cell line for studying mast cell degranulation and inflammatory cytokine release in vitro. After stimulating the RBL-2H3 cells with IgE, ST at concentrations of 10,50 , or 100 $\mu \mathrm{g} / \mathrm{mL}$ was added to the cell cultures. Cell viability, inflammatory cytokines (IL-6, IL-13, IL-4, TNF- $\alpha$, and IFN- $\gamma$ ), anti-inflammatory cytokine IL-10, and degranulation ability were examined 48 and 72 hours after administration of ST. The markers of inflammation and allergic reaction, IFN- $\gamma$, TNF- $\alpha$, IL-4, and IL-6, were suppressed, especially after treatment with $100 \mu \mathrm{g} / \mathrm{mL}$ ST. However, the anti-inflammation marker IL-10 was also suppressed by ST. Trend analysis showed that a higher ST concentration was associated with lower IFN- $\gamma$ and TNF- $\alpha$ levels. Moreover, degranulation of RBL-2H3 cells was assessed by measuring the release of $\beta$ hexosaminidase, which was suppressed by ST at $10 \mu \mathrm{g} / \mathrm{mL}$. This study showed an immunomodulatory effect of ST at the cellular level and suggests the role of ST in treating allergic diseases.

\section{Introduction}

Mast cells are widely distributed at the mucosal interface and thus play an important role in allergic diseases, such as urticaria, atopic dermatitis, allergic rhinitis, and asthma. Mast cells can be activated by IgE through the high-affinity IgE receptor (FceRI) and produce diverse mediators that can promote or downregulate inflammation [1,2]. Mobilization of $\mathrm{Ca}^{2+}$ in response to IgE receptor-mediated signaling is a key process in mast cell activation [3]. Allergic skin diseases, such as urticaria and atopic dermatitis, are highly related to the degranulation of mast cells and the balance between inflammatory and anti-inflammatory cytokines, such as interleukin- (IL-) 4, IL-6, IL-10, IL-13, interferon gamma $(\mathrm{IFN}-\gamma)$, and tumor necrosis factor alpha (TNF- $\alpha)[4,5]$. Therefore, to study the pharmacologic effects of allergic skin diseases, an inducible mast cell line is needed.

Currently, three mast cell lines (HMC-1, LAD2, and LUVA cells) and one basophil cell line (RBL-2H3 cells) are commonly used to study allergic reactions, and here RBL$2 \mathrm{H} 3$ cells were chosen to examine the anti-inflammatory effects of Schizonepeta tenuifolia, a herb well known for the 
treatment of allergic skin diseases [6]. HMC-1 cells, which are like immature mast cells, can only express small amounts of tryptase and chymase, with nearly no functional FceRI on the cell surface $[7,8]$. LAD2 cells are not suitable for these studies, as they have an unstable phenotype and cell doubling time [9]. LUVA cells, which are derived from patients without mast cell-associated diseases, have the advantage of growth in cell cultures without requiring additional growth factors. However, studies on allergic reactions using LUVA cells are still limited. Although derived from basophilic leukemia cells in neonatal Wistar rats, RBL-2H3 cells share similar characteristics to mast cells, and therefore RBL-2H3 cells have been extensively used as a good model for mast cell IgEmediated degranulation [10-13].

Schizonepeta tenuifolia (ST) Briq., which belongs to the family Lamiaceae, is an herbal medicine that has been widely used for thousands of years in China, Taiwan, Japan, and Korea. The dried aerial part of ST is applied clinically for diseases such as allergic skin disease, inflammatory skin disease, infectious skin disease, and the common cold [14, 15]. For this reason, we hypothesize that ST has anti-inflammation and antidegranulation effects on mast cells. Choi et al. stated that ST inhibited 2,4-dinitrochlorobenzene- (DNCB-) induced atopic dermatitis in mice by the suppression of IgE, TNF- $\alpha$, and IL- 6 and by nuclear factor kappa-lightchain-enhancer of activated B cells (NF- $\kappa$ B) activation, as well as through mitogen-activated protein kinase (MAPK) activity [16]. Wang et al. also presented the antioxidant and anti-inflammatory role of aqueous extracts of ST in the carrageenan-induced inflammatory response in mice, and the volatile oil from ST also can relieve carrageenaninduced pleurisy in rat $[17,18]$. ST also regulates cytokinecytokine receptor interaction, MAPK, and Toll-like receptor (TLR) signaling pathways in HMC-1 mast cells [19]. Methanol extracts of ST inhibit the substance p-induced itch-scratch response in mice [20]. Furthermore, aqueous extracts of ST inhibit mast cell-mediated immediate-type hypersensitivity, suggesting that ST has the potential to treat allergic diseases including urticaria, angioedema, allergic asthma, and allergic rhinitis [21]. To prove the hypothesis about the immunomodulatory abilities of ST, a water extract of ST was used to suppress inflammation and degranulation of mast cells using the RBL-2H3 cell line in vitro in this study.

\section{Materials and Methods}

2.1. Preparation of ST Water Extract. A sample of ST was obtained from a pharmaceutical factory with good manufacturing practices, Chuang Song Zong Co., Ltd. (Kaohsiung, Taiwan). ST was extracted using water (weight $5.2 \mathrm{~g}$, water content $50.47 \%$ ) and filtered through a $0.22 \mu \mathrm{M}$ syringe filter. The extract was stored at $4^{\circ} \mathrm{C}$ and diluted to the required concentrations on the day of use.

2.2. RBL-2H3 Cell Culture. RBL-2H3 cells were obtained from the Bioresource Collection and Research Center (Hsinchu, Taiwan). RBL-2H3 cells were cultured in DMEM supplemented with $15 \%(\mathrm{v} / \mathrm{v})$ heat-inactivated FBS, 2\% glutamine, and $100 \mathrm{U} / \mathrm{mL}$ penicillin. Cells were grown at $37^{\circ} \mathrm{C}$ in an atmosphere of 5\% $\mathrm{CO} 2$ and $95 \%$ air. The cells were detached from T75 flasks using a trypsin-EDTA solution and resuspended in fresh medium for subsequent experiments.

2.3. Cell Viability Assay (MTT Assay). Cell viability was determined using a 3-[4,5-dimethylthiazol-2-yl]-2,5-diphenyltetrazolium bromide (MTT) colorimetric assay (SigmaAldrich). RBL-2H3 cells were grown in 96-well plates $(5 \times 105$ cells $/ \mathrm{mL}$, each well containing $4 \times 104$ cells). After treating RBL-2H3 cells with different concentrations of ST for $48 \mathrm{hrs,}$ cells were treated with $20 \mu \mathrm{L}$ MTT $(5 \mathrm{mg} / \mathrm{mL})$ and then incubated at $37^{\circ} \mathrm{C}$ for $2 \mathrm{hrs}$. Cells were then washed, and the insoluble formazan products were dissolved in $150 \mu \mathrm{L} 0.1 \%$ Triton X-100 acidified isopropanol $(13 \mu \mathrm{L} 37 \% \mathrm{HCl}, 40 \mu \mathrm{L}$ Triton X-100, and $40 \mathrm{~mL}$ isopropanol). After shaking for $15 \mathrm{~min}$, absorbance was measured at the $570 \mathrm{~nm}$ wavelength by spectrophotometry (Bio-Tek Instruments, Winooski, VT, USA). All measurements were made in triplicate, and a total of three independent experiments were performed. Cell viability data were expressed as the percentage relative to the viability in control cell cultures.

2.4. Determination of Cytokine Levels. The inhibitory effects of ST at concentrations of 10,50 , or $100 \mu \mathrm{g} / \mathrm{mL}$ on the IgEstimulated release of cytokines in RBL-2H3 cells were evaluated. For this, RBL-2H3 cells were activated with antidinitrophenyl (DNP) IgE (0.5 $\mu \mathrm{g} / \mathrm{ml}$; Sigma-Aldrich) overnight, and then the three different concentrations of ST were added for $48 \mathrm{hrs}$ and $72 \mathrm{hrs}$, separately. After treatment, cells were challenged with DNP-bovine serum albumin (BSA; $100 \mathrm{ng} / \mathrm{ml}$; Sigma-Aldrich) for $45 \mathrm{~min}$ at $37^{\circ} \mathrm{C}$ and then incubated on ice for $10 \mathrm{~min}$. Culture supernatants from RBL-2H3 cells were assayed in triplicate for IL-4, IL-6, IL-10, IL-13, IFN- $\gamma$, and TNF- $\alpha$ using ELISA kits according to the manufacturer's instructions (eBioscience, San Diego, CA, USA).

2.5. Analysis of $\beta$-Hexosaminidase Release. To measure $\beta$ hexosaminidase release, RBL-2H3 cells were trypsinized and centrifuged, before resuspension in DMEM-FCS and stimulated with monoclonal anti-DNP IgE $(0.5 \mu \mathrm{g} / \mathrm{ml}$; SigmaAldrich) overnight. The cells were washed with Siraganian buffer $(119 \mathrm{mM} \mathrm{NaCl}, 5 \mathrm{mM} \mathrm{KCl}, 5.6 \mathrm{mM}$ glucose, $0.4 \mathrm{mM}$ $\mathrm{MgCl}_{2}, 25 \mathrm{mM}$ PIPES, $40 \mathrm{mM} \mathrm{NaOH}, 1 \mathrm{mM} \mathrm{CaCl}_{2}$, and $0.1 \%$ $\mathrm{BSA}$ ) and then treated with or without $\mathrm{ST}$ at the indicated concentrations. After incubation for $10 \mathrm{~min}$ at $37^{\circ} \mathrm{C}$, the cells were challenged with DNP-BSA (100 ng/ml; Sigma-Aldrich) for $45 \mathrm{~min}$ at $37^{\circ} \mathrm{C}$ and then put on ice for $10 \mathrm{~min}$. Culture supernatants were incubated with $1 \mathrm{mM}$ p-nitrophenyl-Nacetyl-ß-D-glucosaminide (p-NAG; Sigma-Aldrich) for one $\mathrm{hr}$ at $37^{\circ} \mathrm{C}$ and then $0.1 \mathrm{~N} \mathrm{Na} 2 \mathrm{CO} 3 / \mathrm{NaHCO} 3(\mathrm{pH} 10.0)$ was added to stop the reaction. Optical density at $405 \mathrm{~nm}$ was measured. The inhibition of $\beta$-hexosaminidase granule release was calculated using the following equations:

$$
\% \text { of inhibition }=\frac{(\text { Treated }- \text { Blank }- \text { Spontaneous })}{(\text { Control }- \text { Blank }- \text { Spontaneous })},
$$




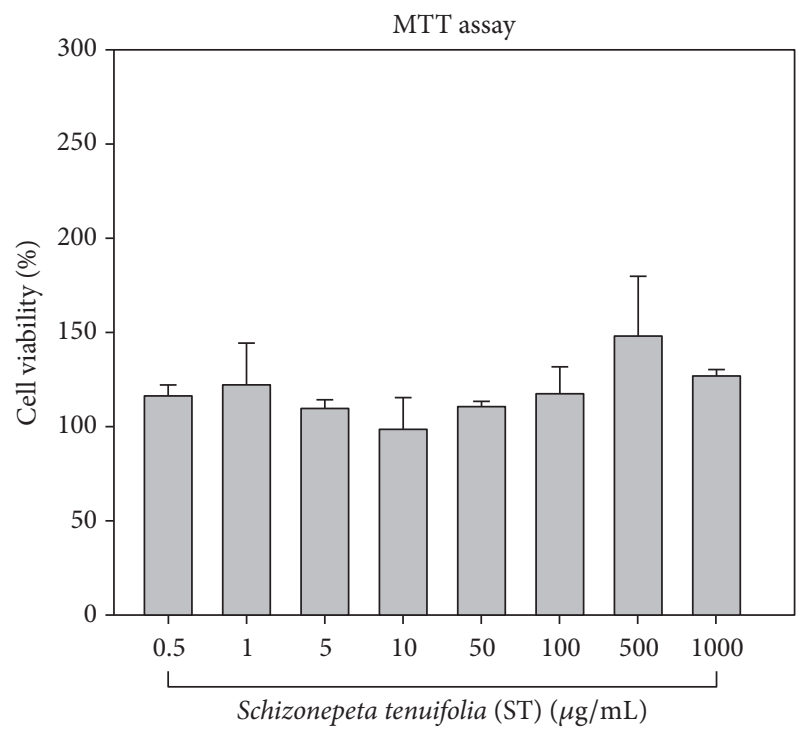

FIGURE 1: Schizonepeta tenuifolia (ST) Briq. has no significant negative effects on RBL-2H3 cells. MTT was used to assess cell viability after treatment with different concentrations of ST. When compared to the control, set as $100 \%$, no cell toxicity was noted after treatment with 10,50 , and $100 \mu \mathrm{g} / \mathrm{mL}$ ST.

where the Control was defined as the normal allergen-IgE response evoked without ST added; Treated was defined as the normal allergen-IgE response evoked with added ST; Blank was only ST and substrate added to the ELISA plate; and Spontaneous meant that the allergen-IgE response was not evoked and ST was not added.

2.6. Statistical Methods. All data and statistic tests were processed using SPSS (version 15.0, Chicago, IL, USA) and represented as mean \pm standard error of mean (SEM). The differences between groups were analyzed using the nonparametric Wilcoxon signed-rank test. The trend analyses for dose-dependent relations between ST concentration and inflammatory cytokines were performed using one-way analysis of variance (ANOVA). A $p$ value less than 0.05 was considered statistically significant.

\section{Results}

3.1. ST Has No Significant Influence on RBL-2H3 Cell Viability. First, we confirmed there was no cytotoxicity following treatment with ST at any concentration. Even at high concentrations of ST treatment $(1000 \mu \mathrm{g} / \mathrm{mL})$, cell toxicity was not observed (Figure 1). We used ST at concentrations of 10, 50, and $100 \mu \mathrm{g} / \mathrm{mL}$ in the following experiments.

\subsection{Effects of ST on Proinflammatory Cytokine Production in} IgE-Stimulated RBL-2H3 Cells. As showed in Figure 2, IFN$\gamma$, IL-4, IL-6, TNF- $\alpha$, and IL-13 significantly decreased in the ST group when compared to the control group. IL-4 in IgE-stimulated RBL-2H3 cells decreased after treatment with ST for 48 and $72 \mathrm{hrs}$, which were both statistically significant compared to controls. The decreases in IL- 4 and TNF- $\alpha$ were most prominent, especially for IL- 4 , as the concentration of IL-4 barely shown in the $100 \mu \mathrm{g} / \mathrm{mL}$ ST treatment group. In addition, the trend analysis showed that higher concentrations of ST may relate to lower levels of IFN$\gamma$ and TNF- $\alpha$.

3.3. Effects of ST on IL-10, an Anti-Inflammatory Cytokine in IgE-Stimulated RBL-2H3 Cells. Figure 3 showed that IL10 , an anti-inflammatory marker in IgE-induced RBL-2H3 cells, decreased after treatment with ST. The concentration of IL-10 lowered as ST concentration increased (trend analysis, $p<0.05$ ), and the concentration of IL-10 was generally lower at $48 \mathrm{hrs}$ but increased at $72 \mathrm{hrs}$, except in cell cultures treated with $100 \mu \mathrm{g} / \mathrm{mL} \mathrm{ST}$, although the difference between 48 and 72 hours of cell culture did not reach significance.

3.4. Effects of ST on $\beta$-Hexosaminidase Release. Furthermore, the release of $\beta$-hexosaminidase was examined to assess the cytokine secretory ability of IgE-stimulated RBL$2 \mathrm{H} 3$ cells. In comparison with the control group, the $\beta$ hexosaminidase level was significantly lower in the group treated with $10 \mu \mathrm{g} / \mathrm{mL} \mathrm{ST}$, but the inhibition of stimulated cells was not observed in the groups treated with 50 or $100 \mu \mathrm{g} / \mathrm{mL}$ ST (Figure 4). The trend analysis showed no dosedependent relationships between different doses of ST and $\beta$ hexosaminidase release.

\section{Discussion}

In this study, we demonstrated that ST may have antiinflammatory effects on IgE-stimulated RBL-2H3 cells, a model for allergic disease, and the effect may not be related to degranulation ability. Levels of IL-4, IL-6, IFN- $\gamma$, and TNF$\alpha$ were all much lower in the ST-treated groups than in the control group, and the decreasing trend seemed roughly both dose- and duration-dependent. In addition, the level of IL13 was lower among the ST treatment group (at $10 \mu \mathrm{g} / \mathrm{mL}$ ), whereby IL-13 is thought to be a marker of urticaria severity [22]. IL-4 was the first cytokine found to be produced by mast cells and is responsible for IL-13 production in mast cells [23]. During the allergic response, mast cells produce IL4 rapidly to stimulate an inflammatory response [24]. Then, IL- 4 raises the production of IL-13 in these cells [25]. IL-6 is an important cytokine for mast cell maturation and the upregulation of histamine production [26]. TNF- $\alpha$ is a potent mast cell chemoattractant, which may promote inflammation among mast cells and subsequent dendritic cell migration [27-29]. In addition to mast cells, ST was reported to suppress both Th1 and Th2 cells, the balance of which is regarded as an important treatment target $[30,31]$. The multicell and extensive immunomodulation effect of ST may be useful for skin diseases, especially when allergy and inflammation are both concerned. IL-10 can serve as a natural regulator of mast cell homeostasis by dampening mast cell FceRI expression, preventing excessive activation and inflammation [32]. Since IL-10 was not lower in the ST treatment groups, this may imply that ST suppresses both the inflammatory and 

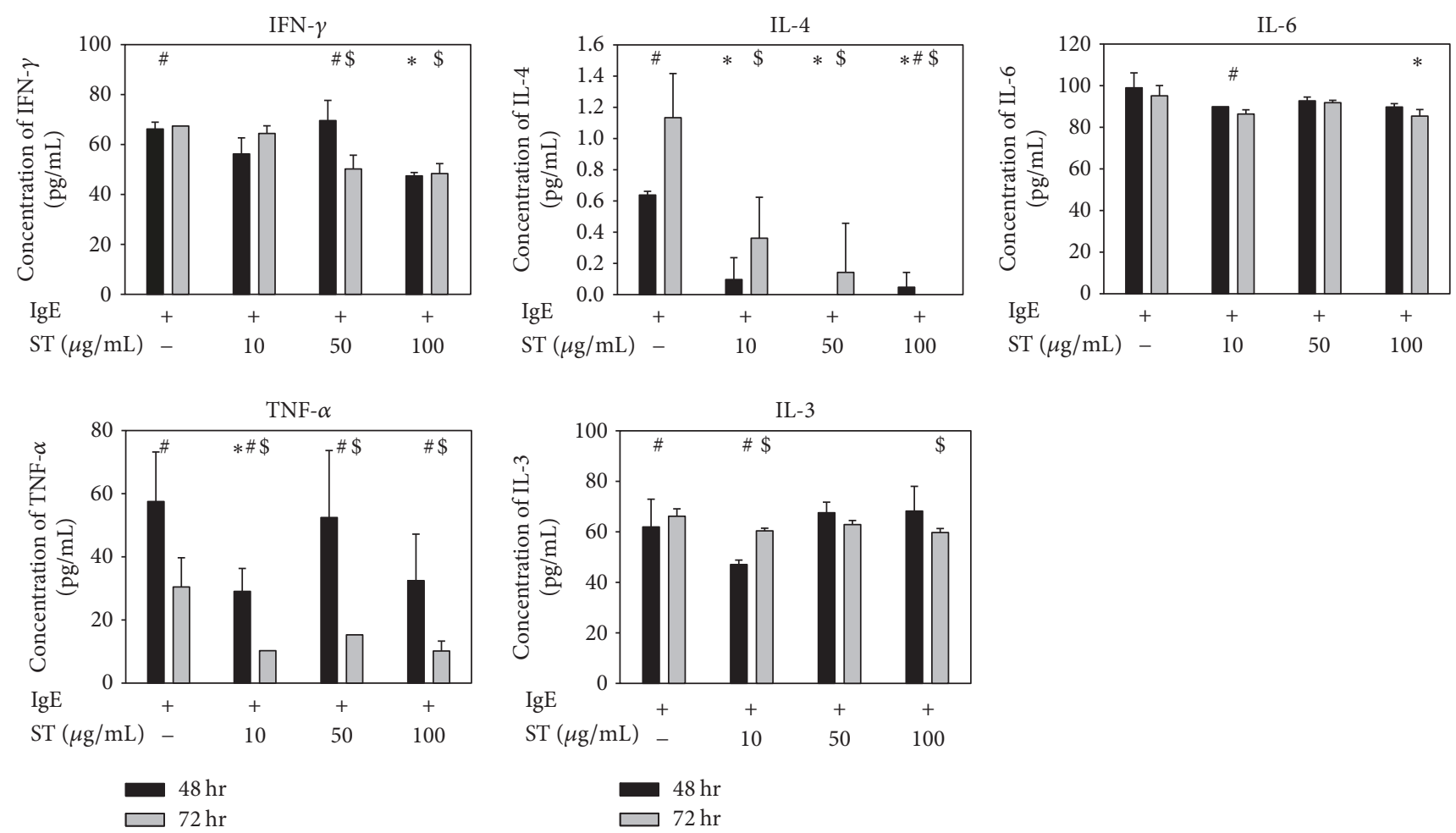

FIGURE 2: The evolution of proinflammatory cytokines 48 and $72 \mathrm{hrs}$ after treating IgE-induced RBL-2H3 cells with 10, 50, or 100 $\mu$ g/mL ST shows that the inflammatory cytokines released by RBL-2H3 cells tend to decrease with increasing doses of ST, especially IFN- $\gamma$ and TNF- $\alpha$. ${ }^{*} p<0.05$ when compared with controls after $48 \mathrm{hrs}$ of ST treatment; ${ }^{\$} p<0.05$ when compared with controls after $72 \mathrm{hrs}$ of ST treatment; and ${ }^{\#} p<0.05$ when comparing data between 48 and $72 \mathrm{hrs}$ of treatment.

anti-inflammatory response at the same time. Since mast cells may have both immunostimulatory and immunosuppressive actions, the dual suppression effect may be needed for mast cell related skin diseases [33].

Moreover, the immunomodulation effect of ST seems less relevant to the inhibition of mast cell degranulation, which may have two explanations: certain inflammatory cytokines, such as TNF and IL-6, were not released from mast cells by degranulation, or ST suppressed the release of inflammatory cytokines through other pathways. Allergic symptoms are caused by both unbalanced cytokines and the abnormal degranulation of mast cells. The activation of mast cells contributes to the pathophysiology of many allergic diseases through the synthesis and release of numerous proinflammatory mediators and cytokines. Mast cells can express different receptors and ligands on the cell surface, and after activation they release mediators such as histamines, leukotrienes, and cytokines chemokines; all of these mediators and cell surface molecules can promote inflammation in the skin [34]. Mast cells may also be able to selectively release proinflammatory mediators without the degranulation typical of allergic reactions; for example, IL-1 may induce the selective release of IL-6 [33, 35]. Also, TNF and IFN- $\gamma$ could be released without evidence of degranulation [33]. In contrast, ST may suppress inflammation via the activation of toll-like receptor 4 (TLR4), which may further decrease the release of TNF- $\alpha$ while leaving degranulation unaffected $[35,36]$.
Nevertheless, the unaffected degranulation and suppressed secretion of IL-10 may be the reason that ST is commonly used with other herbs when treating allergic skin diseases; for example, ST is a part of a complicated herbal network for the treatment of urticaria $[6,37]$. ST is the major ingredient in the most commonly used herbal prescription for urticaria and the twelve other herbs used may complement the treatment effect by suppressing histamine release and increasing the anti-inflammation effects [38]. A more extensive effect on urticaria can thus be found when these herbs are used in combination.

Finally, we found RBL-2H3 cells to be a feasible in vitro model to examine the mechanisms and effects of compounds on urticaria. In our study, the anti-inflammatory response in RBL-2H3 cells was like findings describing the response in the mast cell model, HMC-1 cells, as both systems showed the IL- 6 and TNF- $\alpha$ suppression $[19,21]$. Although basophils and mast cells have different cellular origins, both cells are important in chronic urticaria for the release of histamine when exposed to the susceptible allergens [39, 40]. Moreover, basophils share many similarities with mast cells, such as similar cell morphology under staining, intracellular granule contents, and the secretory route of cytokines [10]. These features make RBL-2H3 cells a good candidate cell line to examine the activity of urticaria at the cellular level and could also be used as a drug screening platform. However, we found that some secretory cytokines may have relatively 


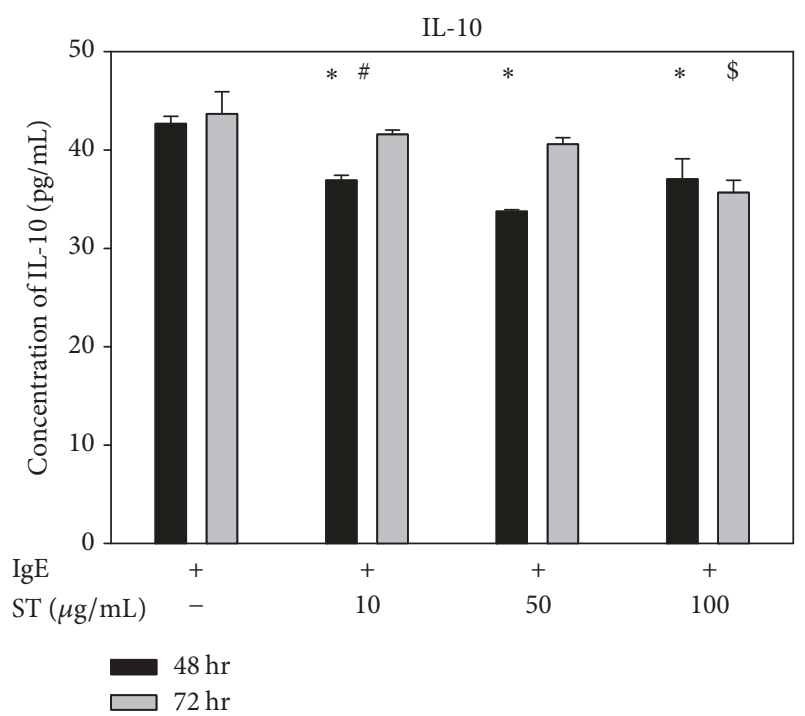

FIgURE 3: The anti-inflammatory cytokine IL-10 did not increase in RBL-2H3 cells subjected to IgE and ST. Bars show the evolution of IL-10 48 and $72 \mathrm{hrs}$ after treating IgE-induced RBL-2H3 cells with ST at 10,50 , or $100 \mu \mathrm{g} / \mathrm{mL} .{ }^{*} p<0.05$ when compared with controls after $48 \mathrm{hrs}$ of ST treatment; ${ }^{\$} p<0.05$ when compared with controls after 72 hrs of ST treatment; and ${ }^{\#} p<0.05$ when comparing data between 48 and $72 \mathrm{hrs}$ of treatment.

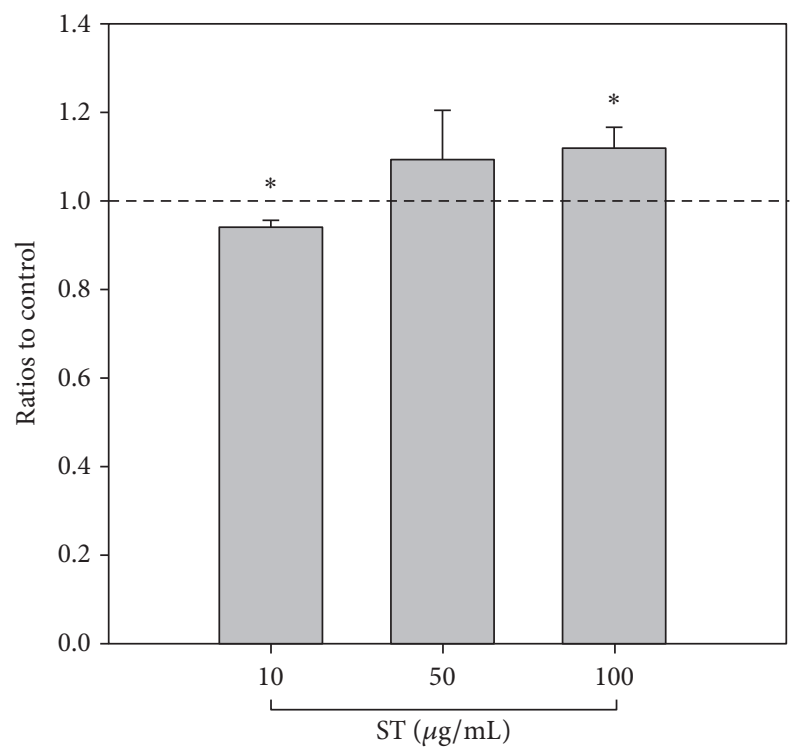

Figure 4: $\beta$-Hexosaminidase release decreased in IgE-stimulated RBL- $2 \mathrm{H} 3$ cells subjected to the ST treatment $(10 \mu \mathrm{g} / \mathrm{mL})$. However, the release of $\beta$-hexosaminidase seemed higher after treatment with 50 and $100 \mu \mathrm{g} / \mathrm{mL} \mathrm{ST}$. The concentration of $\beta$-hexosaminidase was set to 1 in the control group (dashed line). ${ }^{*} p<0.05$ when compared to controls.

large variations under specific conditions, such as the TNF$\alpha$ level at $48 \mathrm{hrs}$ and the IL- 4 level at $72 \mathrm{hrs}$ after stimulated cells were subjected to ST, which has also been seen in other experiments using RBL-2H3 cells [41]. Likewise, a prior report also points out different behaviors between RBL-2H3 cells and mast cells [41]. For this reason, studies evaluating the overall effects of compounds on urticarial should be based on more extensive inflammatory/anti-inflammatory cytokines profiles.

\section{Conclusions}

Mast cells are important sources of cytokines in allergic and inflammatory diseases. Targeting mast cell-derived cytokines could be a beneficial treatment strategy for allergic inflammatory diseases. Currently, broadly immunosuppressive drugs, such as corticosteroids, are used to treat allergic inflammation. Discovering a therapy for allergic inflammatory diseases with fewer side effects was an aim of this study. Based on the existing data, ST may be a possible treatment for allergic inflammatory diseases via targeting anti-inflammatory pathways. ST, a natural Chinese herbal medicine, could bring hope to patients with chronic allergic inflammatory diseases. With further research, additional inflammatory allergic diseases, such as urticaria, atopic dermatitis, asthma, and allergic rhinitis, may benefit from ST treatment. Based on our results, further animal studies and human trials will be necessary to complete this aim. The authors hope that successful experiments and trials could introduce ST as a novel treatment for the allergic inflammatory disease to improve patients' quality of life.

\section{Conflicts of Interest}

All authors declare that there are no conflicts of interest.

\section{Acknowledgments}

This work was funded by the Chang Gung Memorial Hospital (CMRPG3E0031). The authors would like to acknowledge Anthony Abram (https://www.uni-edit.net) for editing and proofreading this manuscript.

\section{References}

[1] S. J. Galli and M. Tsai, "IgE and mast cells in allergic disease," Nature Medicine, vol. 18, no. 5, pp. 693-704, 2012.

[2] C. Ng, K. L. Hon, J. S. C. Kung, N. H. Pong, T.-F. Leung, and C. $\mathrm{K}$. Wong, "Hyper IgE in childhood eczema and risk of asthma in Chinese children," Molecules, vol. 21, no. 6, article no. 753, 2016.

[3] D. Holowka, N. Calloway, R. Cohen et al., "Roles for Ca2+ mobilization and its regulation in mast cell functions," Frontiers in Immunology, vol. 3, no. MAY, Article ID Article 104, 2012.

[4] B. D. Modena, K. Dazy, and A. A. White, "Emerging concepts: mast cell involvement in allergic diseases," Translational Research, vol. 174, pp. 98-121, 2016.

[5] H. Alenius, D. Laouini, A. Woodward et al., "Mast cells regulate IFN- $\gamma$ expression in the skin and circulating IgE levels in allergen-induced skin inflammation," The Journal of Allergy and Clinical Immunology, vol. 109, no. 1, pp. 106-113, 2002.

[6] Y. H. Lin, Y. C. Chen, S. Hu, H. Y. Chen, J. L. Chen, and S. H. Yang, "Identifying core herbal treatments for urticaria using Taiwan's nationwide prescription database," Journal of Ethnopharmacology, vol. 148, no. 2, pp. 556-562, 2013. 
[7] M. Sundström, H. Vliagoftis, P. Karlberg et al., "Functional and phenotypic studies of two variants of a human mast cell line with a distinct set of mutations in the c-kit proto-oncogene," The Journal of Immunology, vol. 108, no. 1, pp. 89-97, 2003.

[8] G. Nilsson, T. Blom, M. Kusche-Gullberg et al., "Phenotypic characterization of the human mast-cell line HMC-1," Scandinavian Journal of Immunology, vol. 39, no. 5, pp. 489-498, 1994.

[9] T. M. Laidlaw, J. W. Steinke, A. M. Tiñana et al., "Characterization of a novel human mast cell line that responds to stem cell factor and expresses functional FceRI," The Journal of Allergy and Clinical Immunology, vol. 127, no. 3, pp. 815-822, 2011.

[10] E. Passante and N. Frankish, "The RBL-2H3 cell line: its provenance and suitability as a model for the mast cell," Inflammation Research, vol. 58, no. 11, pp. 737-745, 2009.

[11] W.-J. Kim, H.-S. Cha, M.-H. Lee, S.-Y. Kim, S. H. Kim, and T.-J. Kim, "Effects of Cymbidium Root Ethanol Extract on Atopic Dermatitis," Evidence-Based Complementary and Alternative Medicine, vol. 2016, Article ID 5362475, 2016.

[12] W. Mao, Y. Sun, J. Mao et al., "Inhibitory Effects of Angelica Polysaccharide on Activation of Mast Cells," Evidence-Based Complementary and Alternative Medicine, vol. 2016, pp. 1-10, 2016.

[13] H. Matsuda, S. Nakamura, and M. Yoshikawa, "Degranulation Inhibitors from Medicinal Plants in Antigen-Stimulated Rat Basophilic Leukemia (RBL-2H3) Cells," CHEMICAL \& PHARMACEUTICAL BULLETIN, vol. 64, no. 2, pp. 96-103, 2016.

[14] H.-Y. Chen, Y.-H. Lin, S. Hu, S.-H. Yang, J.-L. Chen, and Y.C. Chen, "Identifying Chinese herbal medicine network for eczema: Implications from a nationwide prescription database," Evidence-Based Complementary and Alternative Medicine, vol. 2015, Article ID 347164, 2015.

[15] W. Liu, H.-L. Jiang, and B. Mao, "Chinese herbal medicine for postinfectious cough: a systematic review of randomized controlled trials," Evidence-Based Complementary and Alternative Medicine, vol. 2013, Article ID 906765, 14 pages, 2013.

[16] Y. Y. Choi, M. H. Kim, J.-H. Kim et al., "Schizonepeta tenuifolia inhibits the development of atopic dermatitis in mice," Phytotherapy Research, vol. 27, no. 8, pp. 1131-1135, 2013.

[17] M.-Q. Shan, Y. Qian, S. Yu et al., "Anti-inflammatory effect of volatile oil from Schizonepeta tenuifolia on carrageenininduced pleurisy in rats and its application to study of appropriate harvesting time coupled with multi-attribute comprehensive index method," Journal of Ethnopharmacology, vol. 194, pp. 580586, 2016.

[18] B.-S. Wang, G.-J. Huang, H.-M. Tai, and M.-H. Huang, "Antioxidant and anti-inflammatory activities of aqueous extracts of Schizonepeta tenuifolia Briq," Food and Chemical Toxicology, vol. 50, no. 3-4, pp. 526-531, 2012.

[19] S.-H. Sohn, S. Cho, E. S. Ji et al., "Microarray analysis of the gene expression profile of HMC-1 mast cells following Schizonepeta tenuifolia Briquet treatment," Cellular Immunology, vol. 277, no. 1-2, pp. 58-65, 2012.

[20] C. Tohda, Y. Kakihara, K. Komatsu, and Y. Kuraishi, "Inhibitory effects of methanol extracts of herbal medicines on substance P-induced itch-scratch response," Biological \& Pharmaceutical Bulletin, vol. 23, no. 5, pp. 599-601, 2000.

[21] T.-Y. Shin, H.-J. Jeong, S.-M. Jun et al., "Effect of Schizonepeta tenuifolia extract on mast cell-mediated immediate-type hypersensitivity in rats," Immunopharmacology and Immunotoxicology, vol. 21, no. 4, pp. 705-715, 1999.

[22] Y. Bae, K. Izuhara, S. Ohta et al., "Periostin and interleukin13 are independently related to chronic spontaneous urticaria,"
Allergy, Asthma \& Immunology Research, vol. 8, no. 5, pp. 457460, 2016.

[23] J. J. A. McLeod, B. Baker, and J. J. Ryan, "Mast cell production and response to IL-4 and IL-13," Cytokine, vol. 75, no. 1, pp. 5761, 2015.

[24] A. M. Gilfillan and C. Tkaczyk, "Integrated signalling pathways for mast-cell activation," Nature Reviews Immunology, vol. 6, no. 3, pp. 218-230, 2006.

[25] H. Toru, R. Pawankar, C. Ra, J. Yata, and T. Nakahata, "Human mast cells produce IL-13 by high-affinity IgE receptor crosslinking: Enhanced IL-13 production by IL-4-primed human mast cells," The Journal of Allergy and Clinical Immunology, vol. 102, no. 3, pp. 491-502, 1998.

[26] P. Conti, D. Kempuraj, M. Di Gioacchino et al., "Interleukin-6 and mast cells," Allergy Asthma Proc, vol. 23, no. 5, pp. 331-335, 2002.

[27] H. Suto, S. Nakae, M. Kakurai, J. D. Sedgwick, M. Tsai, and S. J. Galli, "Mast cell-associated TNF promotes dendritic cell migration," The Journal of Immunology, vol. 176, no. 7, pp. 41024112, 2006.

[28] E. Brzezińska-Błaszczyk, A. Pietrzak, and A. H. Misiak-Tłoczek, "Tumor necrosis factor (TNF) is a potent rat mast cell chemoattractant," Journal of Interferon \& Cytokine Research, vol. 27, no. 11, pp. 911-919, 2007.

[29] O. H. Kang, J. G. Choi, J. H. Lee, and D. Y. Kwon, "Luteolin isolated from the flowers of Lonicera japonica suppresses inflammatory mediator release by blocking NF- $\kappa$ B and MAPKs activation pathways in HMC-1 cells," Molecules, vol. 15, no. 1, pp. 385-398, 2010.

[30] H. Kang, Y.-J. Oh, H.-Y. Choi et al., "Immunomodulatory effect of Schizonepeta tenuifolia water extract on mouse Th1/Th2 cytokine production in-vivo and in-vitro," Journal of Pharmacy and Pharmacology, vol. 60, no. 7, pp. 901-907, 2008.

[31] Y.-Y. Shao, Y.-M. Zhou, M. Hu et al., "The anti-allergic rhinitis effect of traditional Chinese medicine of Shenqi by regulating mast cell degranulation and Th1/Th2 cytokine balance," Molecules, vol. 22, no. 3, article no. 504, 2017.

[32] S. K. Norton, B. Barnstein, J. Brenzovich et al., "IL-10 Suppresses Mast Cell IgE Receptor Expression and Signaling In Vitro and In Vivo," The Journal of Immunology, vol. 180, no. 5, pp. 28482854, 2008.

[33] T. C. Theoharides, K.-D. Alysandratos, A. Angelidou et al., "Mast cells and inflammation," Biochimica et Biophysica Acta, vol. 1822, no. 1, pp. 21-33, 2012.

[34] I. T. Harvima and G. Nilsson, "Mast cells as regulators of skin inflammation and immunity," Acta Dermato-Venereologica, vol. 91, no. 6, pp. 644-650, 2011.

[35] M.-W. Byun, "Schizonepeta tenuifolia ethanol extract exerts anti-inflammatory activity through the inhibition of TLR4 signaling in lipopolysaccharide-stimulated macrophage cells," Journal of Medicinal Food, vol. 17, no. 3, pp. 350-356, 2014.

[36] H. Sandig and S. Bulfone-Paus, "TLR signaling in mast cells: Common and unique features," Frontiers in Immunology, vol. 3, Article ID Arricle 185, 2012.

[37] H.-Y. Chen, Y.-H. Lin, J.-W. Huang, and Y.-C. Chen, "Chinese herbal medicine network and core treatments for allergic skin diseases: implications from a nationwide database," Journal of Ethnopharmacology, vol. 168, pp. 260-267, 2015.

[38] M.-Z. Xu, W. S. Lee, J.-M. Han et al., "Antioxidant and antiinflammatory activities of $\mathrm{N}$-acetyldopamine dimers from Periostracum Cicadae," Bioorganic \& Medicinal Chemistry, vol. 14, no. 23, pp. 7826-7834, 2006. 
[39] F. D. Lourenço, M. H. Azor, J. C. Santos et al., "Activated status of basophils in chronic urticaria leads to interleukin-3 hyperresponsiveness and enhancement of histamine release induced by anti-IgE stimulus," British Journal of Dermatology, vol. 158, no. 5, pp. 979-986, 2008.

[40] S. S. Saini, "Basophil responsiveness in chronic urticaria," Current Allergy and Asthma Reports, vol. 9, no. 4, pp. 286-290, 2009.

[41] E. Passante, C. Ehrhardt, H. Sheridan, and N. Frankish, "RBL$2 \mathrm{H} 3$ cells are an imprecise model for mast cell mediator release," Inflammation Research, vol. 58, no. 9, pp. 611-618, 2009. 


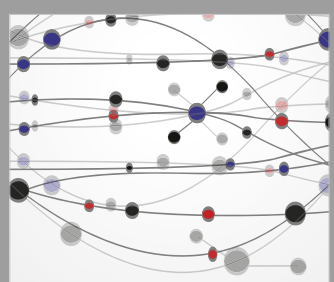

The Scientific World Journal
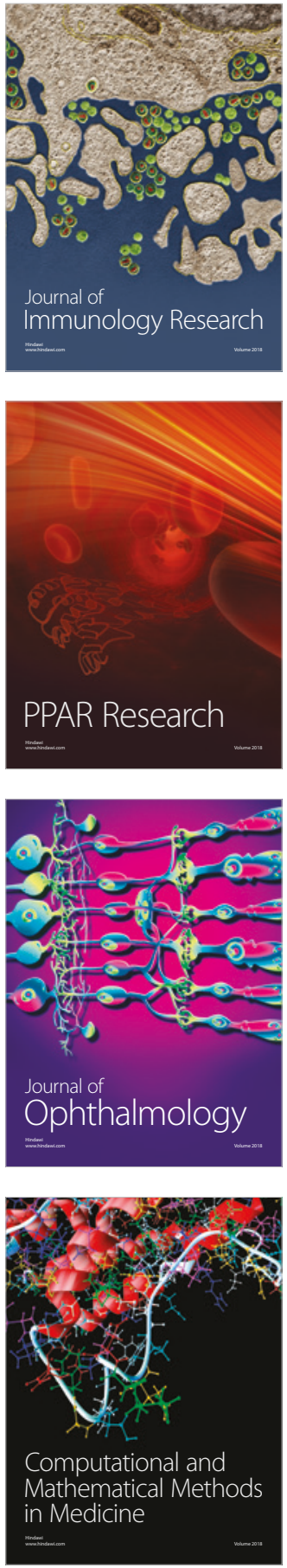

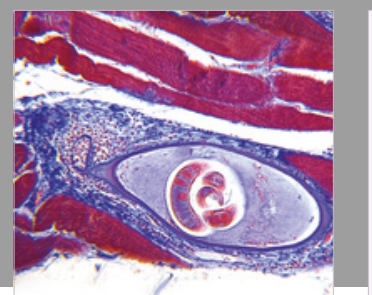

Gastroenterology Research and Practice

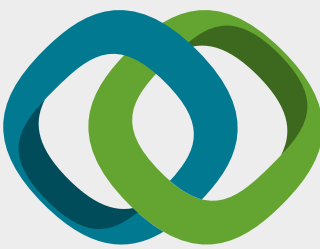

\section{Hindawi}

Submit your manuscripts at

www.hindawi.com
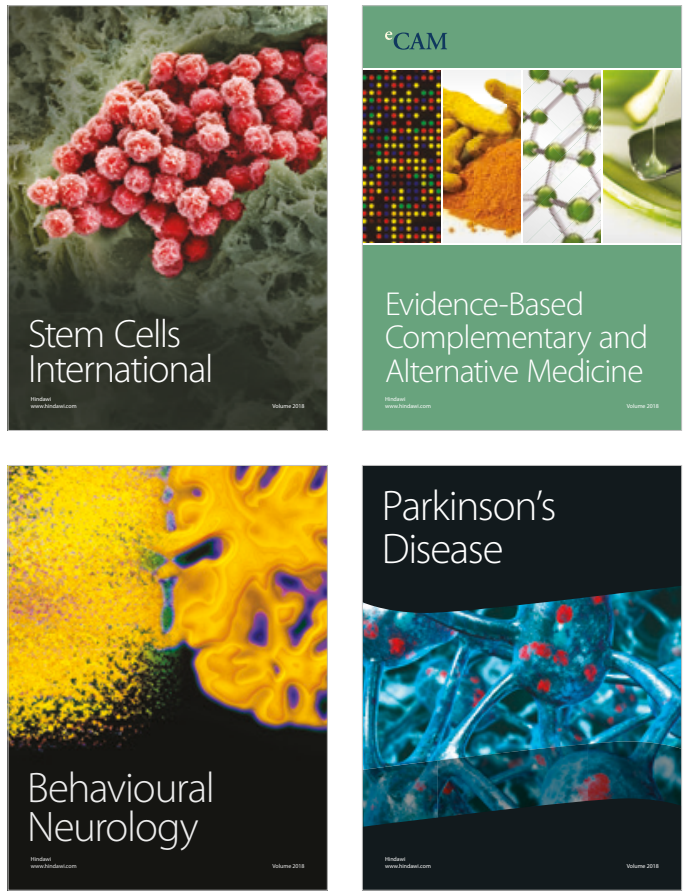

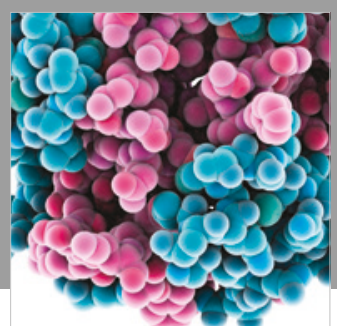

ournal of

Diabetes Research

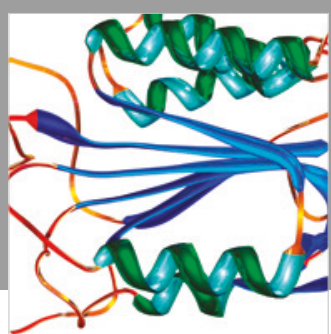

Disease Markers
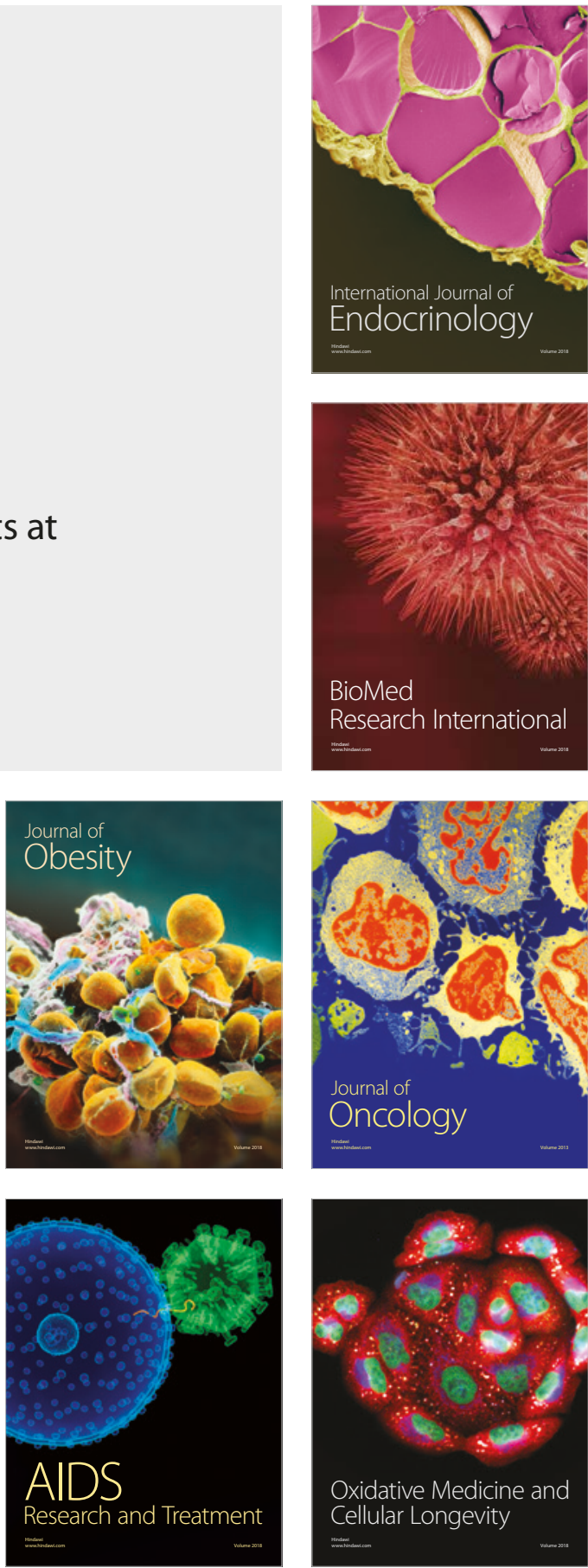